\title{
Karst groundwater vulnerability mapping to the pollution: Case of Dir springs located between EL KSIBA and Ouaoumana (High Atlas, Morocco)
}

\author{
L. ALILI $^{*}{ }^{1}, A$. BOUKDIR $^{1}, M . R$. MASLOUHI $^{2}$ et $H$. IKHMERDI $^{1}$ \\ ${ }^{1}$ Department of Earth Sciences, Faculty of Science and Technology, Sultan Moulay \\ Slimane University, Beni Mellal, Morocco \\ ${ }^{2}$ Oum Er R’bia Hydraulic Basin Agency, Beni Mellal, Morocco
}

\begin{abstract}
The study area is located in the north of the province of Beni Mellal, it covers the Piedmont of the high Atlas between El Ksiba and Ouaoumana. It is characterized by a poorly developed hydrographic network and the presence of very important karstic forms. These forms condition the rapid infiltration to the karstic springs are the subject of this study. In this work we presented a method of mapping the vulnerability to pollution of Karstic springs located between El Ksiba and Ouaoumana. To do this, we have introduced a vulnerability index called $\mathrm{F}$ which takes into account four parameters (EPIK): Development of the Epikarst, importance of the protective cover, infiltration conditions and development of the Karst network. The overlay of the thematic maps of these parameters through a GIS software (ArcGIS) gave us a map of the vulnerability to contamination on the whole hydrogeological basin of the springs.
\end{abstract}

\section{Introduction}

The richness of agriculture, the population growth and the development of socio-economic activities are mainly due to the quantity and quality of the waters. This increasingly growing development can generate negative impacts on the environment in general and on water resources in a particular way. That is why mapping the vulnerability to pollution subject of this study became obligatory for the protection of this resource.

In this work we present the method EPIK adapted for the first time in Switzerland and considered as the initial method adapted to the study and mapping of the intrinsic vulnerability in karstic environments, case of springs located between El Ksiba and Ouaoumana. It is based on four criteria at stake, namely development of the Epikarst, importance of the protective cover, conditions of infiltration and development of the Karst network, with an indexing system for each of the criteria, then a calculation of Weighting with fixed coefficients is carried out.

This method is used to define a protection factor $F$ using the calculation of the Elemental Criteria index classified as vulnerability slices.

Email* : aliligeomatique@gmail.com 


\section{Description of the study area}

The study area is located in the north of the province of Beni Mellal, it covers the piedmont of the mountain between El Ksiba and Ouaoumana. The Dir is thus the transition zone between the plain and the mountain.

This area is traversed longitudinally by the Oum Er R'Bia river and also by the national road linking Fez to Beni Mellal this has fostered an important demographic (centres of Ksiba, Zaouiat Ech Cheikh and Ouaoumana) and an intensification of Socio-economic activities (livestock, industry, tourism, and quarries). The present study focused on thirteen springs in the Dir that are: Tamda, Ouarnfaa, Bouddilite, Ou Abdellah amont, Ou Abdellah aval, Tamescourte, Tiguemate, N'ougziza, Igly, Boullmatene, Ait atmane, Boutmarsite et Ait laaidi (figure 1). The Lambert coordinates of the study area are carried over to table 1.
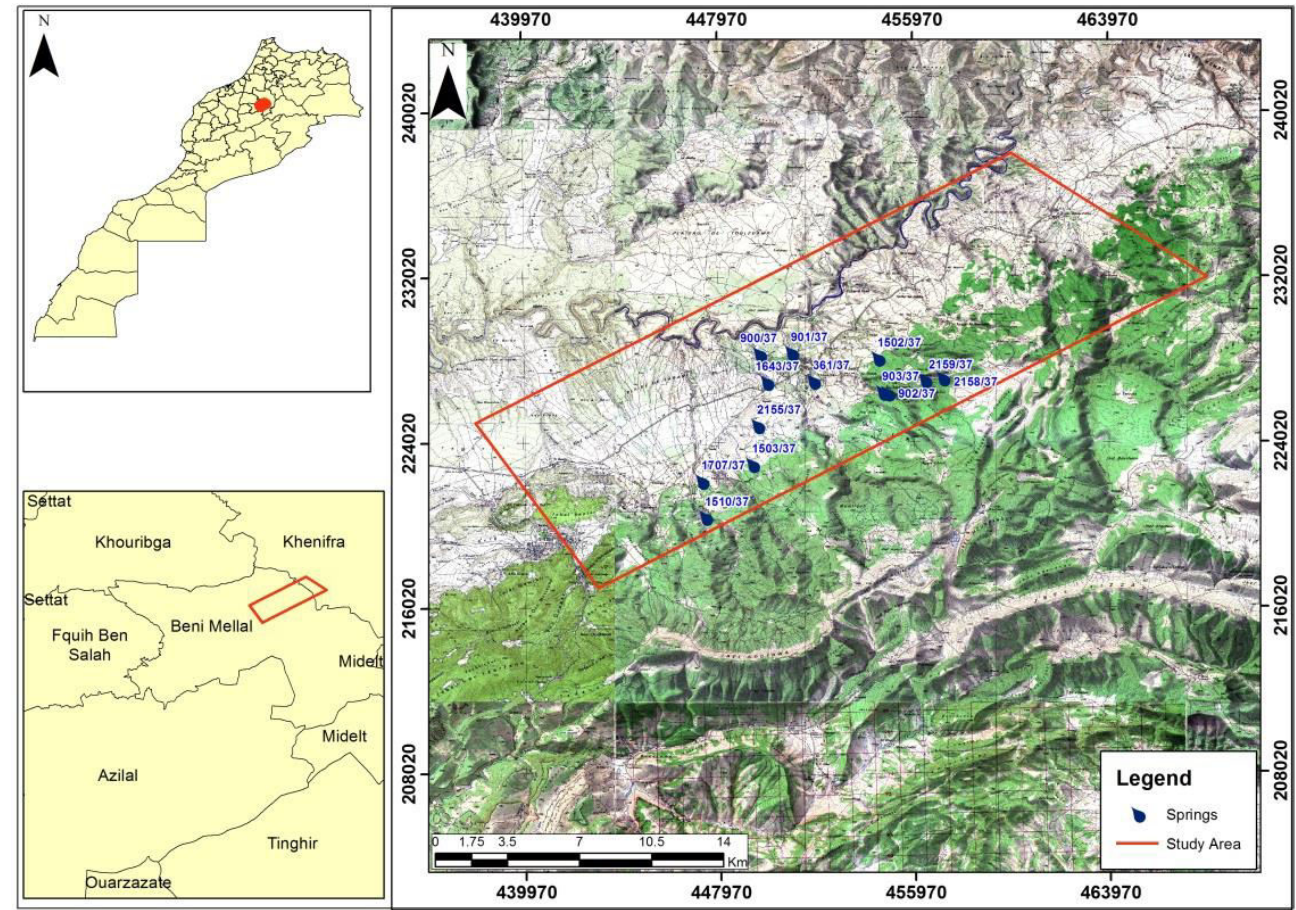

Fig. 1. Geographical location of the area and studied springs

Table 1. Lambert Coordinates limits of the study area.

\begin{tabular}{|c|c|}
\hline $\mathbf{X}(\mathbf{m})$ & $\mathbf{Y}(\mathbf{m})$ \\
\hline 438000 & 225000 \\
\hline 443000 & 217000 \\
\hline 468000 & 232000 \\
\hline 460000 & 238000 \\
\hline
\end{tabular}

is characterized by with regard to the hydrographic network, the study area is drained by the Oum Er R'bia river and by some streams, the most important of which is the Ouaoumana river. 
From a geological point of view, the Atlas of Beni Mellal has a flattened anticline [1], fractured (principal fracturing directions obtained by the treatment of LandSat 8 satellite images is $n$ 40-70 and n 150-180), overlapping to the northwest and Resting on the Dir. It comprises liassic or tertiary aquifer and travertines veneered on the relief of the high atlas (Figure 2).

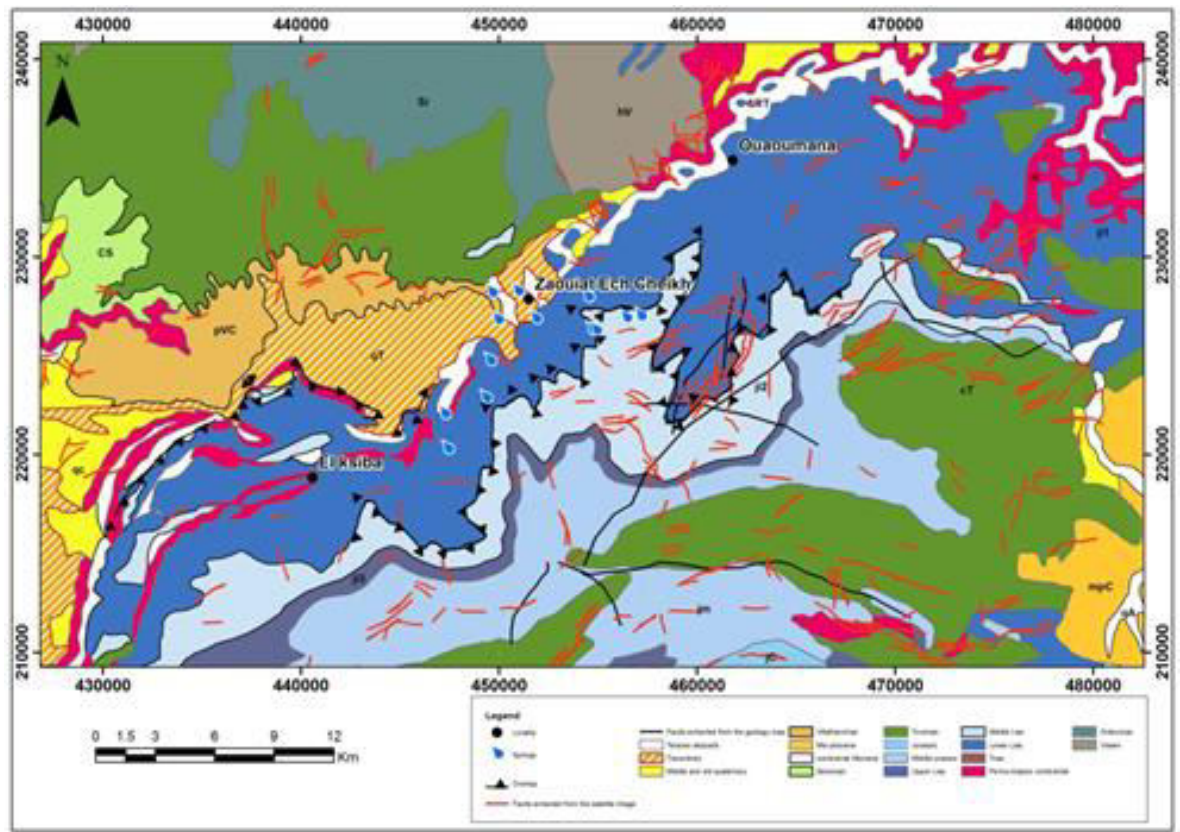

Fig. 2. Geological map of the study area

Triassic and Jurassic form most outcrops in the study area. The first form of the base of scales is represented by marls and red clays in salt. It also contains doleritic basalts in the middle. The Lias or Lower Jurassic includes massive limestones and Dolomites. The Middle Jurassic or Dogger is essentially limestone while the Upper Jurassic is mainly a series of sandstone, continental and red facies. The Triassic and the Jurassic were affected by soft and brittle deformations at the scales origin of El Ksiba [2].

The lower Lias is the most dominant geological formation at the scale of the study area (Figure 2). The Triassic formations are observed locally to the northeast of El Ksiba, flush with the Jbboula river and in contact with the Quaternary formations of the Tadla. The Continental Permo-Triassic is also observed on the right side of the national road from Zaouiat Ech Cheikh to Ouaoumana.

In the mainly Liassic carbonate formations, the phenomena of dissolution resulted in the emergence of a complex system of karstic cavities [3] of varying size and irregular shape.

\section{Materials and methods}

Karstic aquifers are characterized by geomorphological peculiarities and specific hydraulic phenomena such as the existence of important springs, losses, the absence of a surface drainage system, the existence of networks Karsts resulting from the dissolution of 
carbonate rocks; The hydrograms of the springs are typical (rapid and violent flooding, rapid flooding, slow recession), and the quality of the water shows changes in chimism as a function of flow [4]. EPIK (Doerfliger and Zwahlen, 1998) is the first method that has been developed specifically for this type of aquifer [6].

This method based on the specific organisation of flows in the karst environment, consists in the evaluation and the combination of four criteria, namely the development of the Epikarst, the thickness of the protective cover, the infiltration conditions and the Karst network development. These criteria are assessed and weighted by a protection index based on the protective role they provide to groundwater.

\subsection{Description Criteria E, P, I, K: Dir springs Located between EI Ksiba and Ouaoumana Case}

\subsubsection{Epikarst (E)}

E1 (very lowly protective) at E3 (highly protective). Criteria E involves the influence of karstic morphology on the protection of the aquifer. Karstic morphology such as igues, closed depressions and their feeding area will have a very low E1 protection index. The E2 index involves intermediate zones between sinkholes fields and dry valleys. The E3 index will characterize the rest of the catchment (DOERFLIGER N. and ZWAHLEN F., 1998).

For the feeding basin of the springs located between El Ksiba and Ouaoumana, the assessment of the presence and development of the Épikarst was carried out using field observations (karstic modelling and outcrops), geomorphological studies and The examination of high-precision satellites images, In addition to the study of springs recessions.

\subsubsection{Protective Cover $(P)$}

P1 to P4: Criteria P involves the protection of soil cover and soil geological formations. The parameter taken into account here is the least costly and most representative of the protection of a soil to be determined, the thickness. The authors distinguish between a soil directly covering the rocky aquifer (Case A) and another, associated with geological soil formations (Case B). These soil geological formations generally constitute a thickness of low hydraulic conductivity (DOERFLIGER N. and ZWAHLEN F., 1998).

Table 2. Determination of protective cover

\begin{tabular}{|c|c|c|c|}
\cline { 2 - 4 } \multicolumn{1}{c|}{} & & Case A & Case B \\
\cline { 2 - 4 } $\begin{array}{c}\text { No } \\
\text { protection }\end{array}$ & $\mathrm{P} 1$ & $0-20 \mathrm{~cm}$ & \\
\cline { 2 - 4 } & $\mathrm{P} 20-$ & $20-100 \mathrm{~cm}$ sol \\
\hline $\begin{array}{c}\text { Very high } \\
\text { protection }\end{array}$ & $\mathrm{P} 4$ & $>1 \mathrm{~m}$ & $>1 \mathrm{~m}$ \\
\hline
\end{tabular}

The evaluation of the Criteria $P$ in the study area is based mainly on the thickness of the soils, determined by the technical data sheets of the boreholes, the outcroppings in the heels of the roads and the éxamination of the satellite images. 


\subsubsection{Infiltration Conditions (I)}

The Criteria I is used to distinguish between diffuse and concentrated infiltration zones. The method provides low-to-moderate protection for areas feeding direct and concentrated infiltration points (igues and losses), and moderate-to-high protections outside these zones. The feeding basin of the concentrated infiltration points is cut into three protection zones I1, I2, and I3. The rest of the system is associated with I 3 and I4. In conjunction with the relationship of each zone to the igues or loss positions, two other parameters are taken into account in the classification of Criteria I. Topography with slope classes $(10 \% / 10$ $25 \% / 25 \%$ ), and soil type (cropland, grassland and pasture). For the area that is outside the igues feeding basins and losses, the index I 3 corresponds to the slopes $>25 \%$ If they are surveyed by grasslands or pastures and at slopes $>10 \%$ with cropland. The I4 index therefore corresponds to the lowest slopes that do not have a type of land use used in the classification. This point of definition may provide inconsistencies in interpretations of the final vulnerability for these areas.

This Criteria was evaluated using the numerical Terrain Model (MNT) and topographic maps. The entire feeding basin, hated forests, has been assimilated to grasslands and pastures, largely reflecting the real situation. Therefore, the $25 \%$ limit gradient was used for indexing of 1 .

The topographic watershed of the losses and streams fuelling these losses was determined on the Geographic Information System (GIS) using the MNT, with a $30 \mathrm{~m}$ resolution mesh.

\subsubsection{Karst network development $(K)$}

K1 to K3 Criteria $\mathrm{K}$ involves the development of the deep karst aquifer. The K1 index defined a well-developed karst, the K2 index a poorly developed karst and the K3 index a cracked or porous aquifer (DOERFLIGER N. and ZWAHLEN F., 1998).

Note that the nature of the geological banking of the aquifer or unsaturated area, as well as the degree of fracturing of the rock, is not taken into account in this method.

This parameter was evaluated from the direct demonstrations of the karst network (caves, igues) and the study of the flows Chronicles. The study of Hydrograms was carried out for the springs of the study area.

\subsubsection{Calculation of protection factor $F$}

The protection factor $\mathrm{F}$ is calculated with the following basic formula [4-5-6]:

With:

$$
F=\alpha E i+\beta P j+\gamma I k+\delta K l
$$

$\alpha, \beta, \gamma, \delta$ : Weighting factors for each of the criteria;

$\mathrm{Ei}, \mathrm{Pj}, \mathrm{Ik}, \mathrm{Kl}$ : Value of each indexed criteria.

In table 3, we have deferred the assigned weights. As for Figure 9, it presents the criteria summary map. 
Table 3. Relative weights attributed to the factors $\alpha, \beta, \gamma$ and $\delta$

\begin{tabular}{|l|l|l|l|}
\hline $\mathrm{E}$ & $\mathrm{P}$ & $\mathrm{I}$ & $\mathrm{K}$ \\
\hline$\alpha$ & $\beta$ & $\gamma$ & $\delta$ \\
\hline 3 & 1 & 3 & 2 \\
\hline
\end{tabular}

\section{Results and Discussion}

\subsection{Evaluation criteria $E, P, I$ and $K$}

The E map below shows a very lowly protection zone (E1) that extends to areas affected by the morphological and intense tectonic elements (Figure 3), while a moderate protection zone (E2) on Piedmont. The rest correspond to high protection.

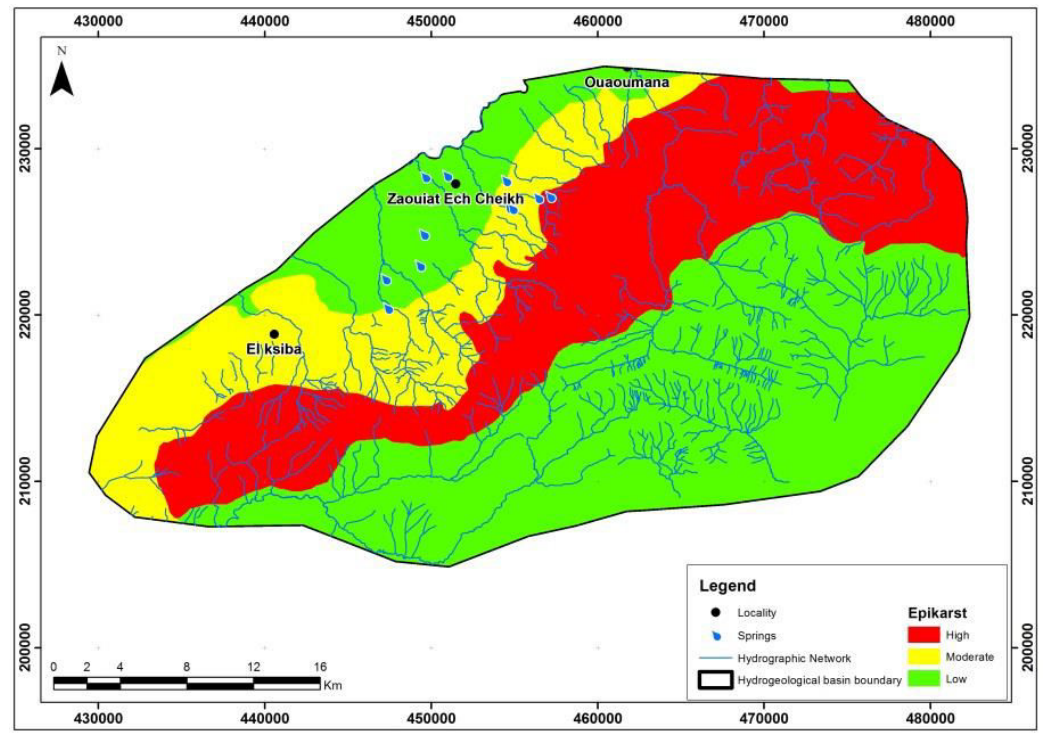

Fig. 3. Epikarst map

The $\mathrm{P}$ map (Figure 4) shows a very lowly protective wide area (P1) in the karst outcropping areas of the High Atlas, a Moderate protection zone (P2) in the Dir where a thin layer of clays is placed directly on limestones, areas of West occupied by the Marly and clayey surface layers are considered to be of high protection (P3) and the Quaternary deposit zones are highly protected (P4). 


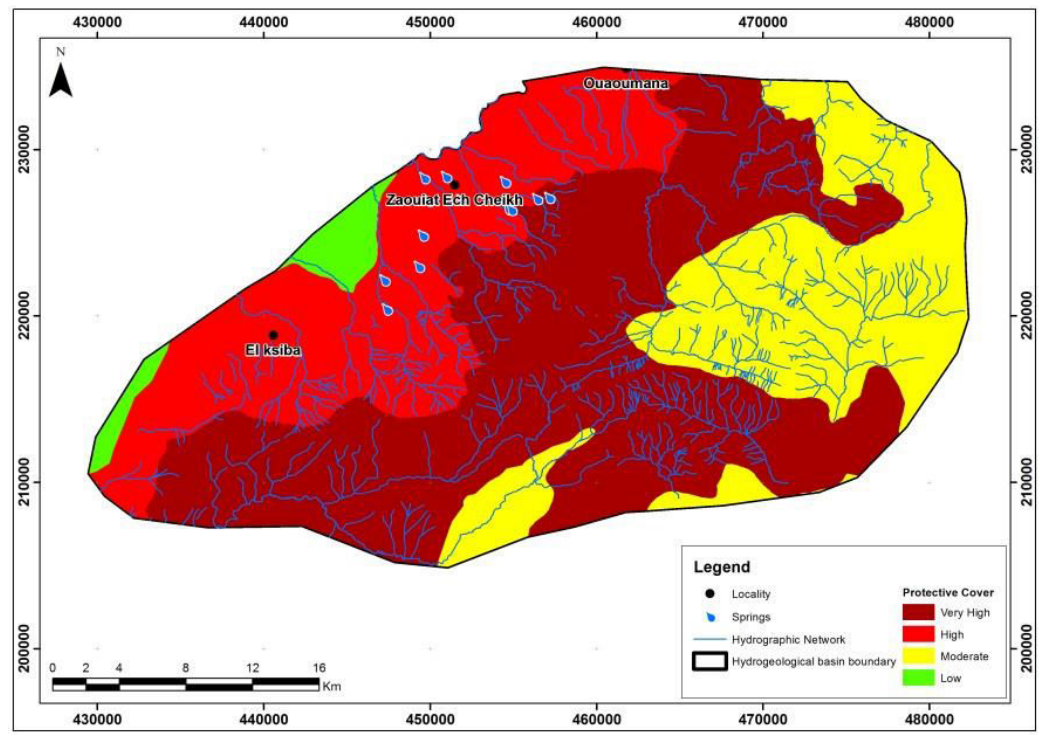

Fig. 4. Protective cover map

The realization of the infiltration map is based on the localization of the morphological elements, the dip and the elements of occupation. As noted above, all losses and sinkholes (Figure 5 and Figure 6) and their feeding pools are mapped as highly vulnerable areas.

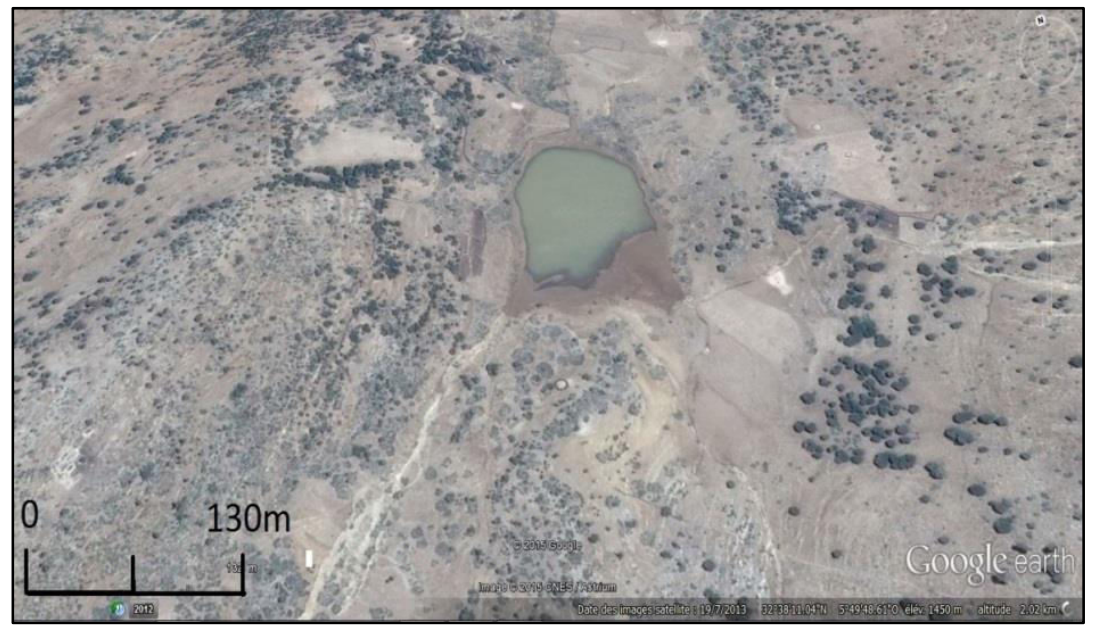

Fig.5. Satellite image of anthropogenic activities around a sinkhole 


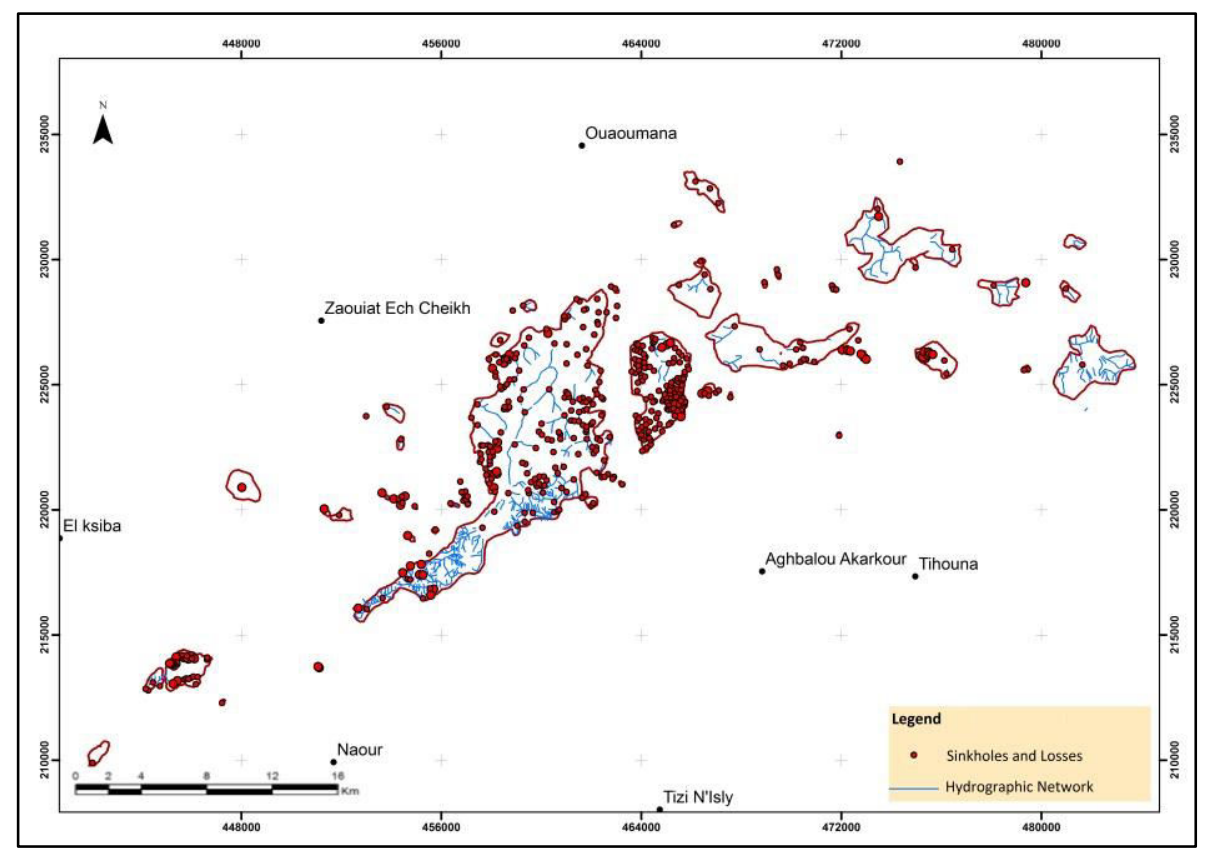

Fig. 6. Position map of sinkholes and losses and their feeding basins

Map I generally presents strong to moderate protection in the study area with the exception of sinkholes and losses and their feeding basins that present low protection (Figure 7).

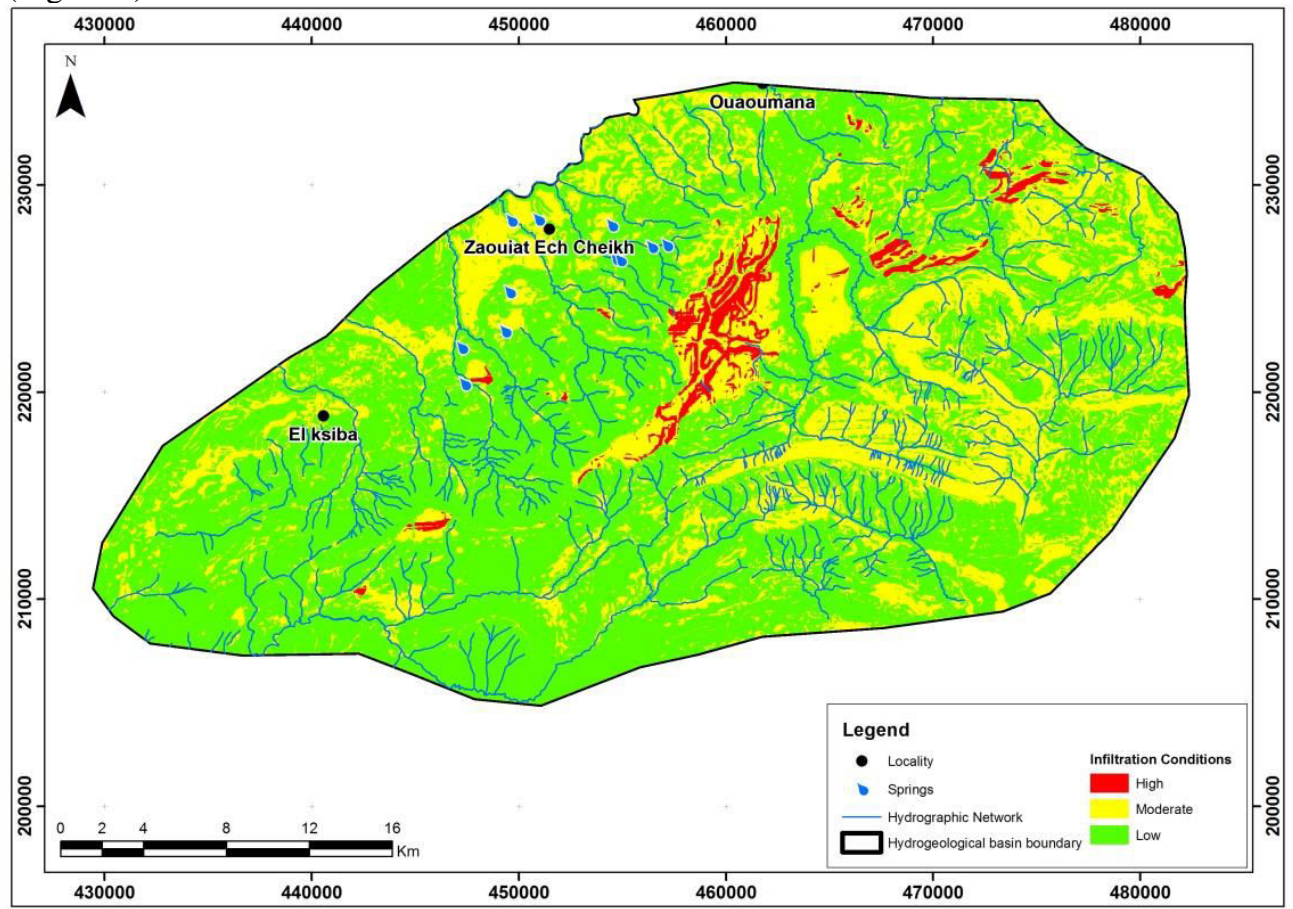

Fig. 7. Infiltration Conditions map 
The hydrograms of the Dir springs are similarly reacting. The springs emerging from the entourage of Zaouiat Ech Cheikh (single outlet) demonstrate the presence of a well developed karst network. The flow rates in high water during the tracing tests carried out on the Atlas of Beni Mellal by BOUCHAOU reach some $100 \mathrm{~m} / \mathrm{h}$ [8].

These speeds indicate the presence of a well-developed karst network.

The K-card has three distinct and homogeneous sets (Figure 8). Areas or surface shapes are classified as K1. The degree of karstification is diminished in passing from the High Atlas to the Tadla Plain, so a K2 indexing has been accepted for Piedmont. The rest of the pond is indexed by $\mathrm{K} 3$.

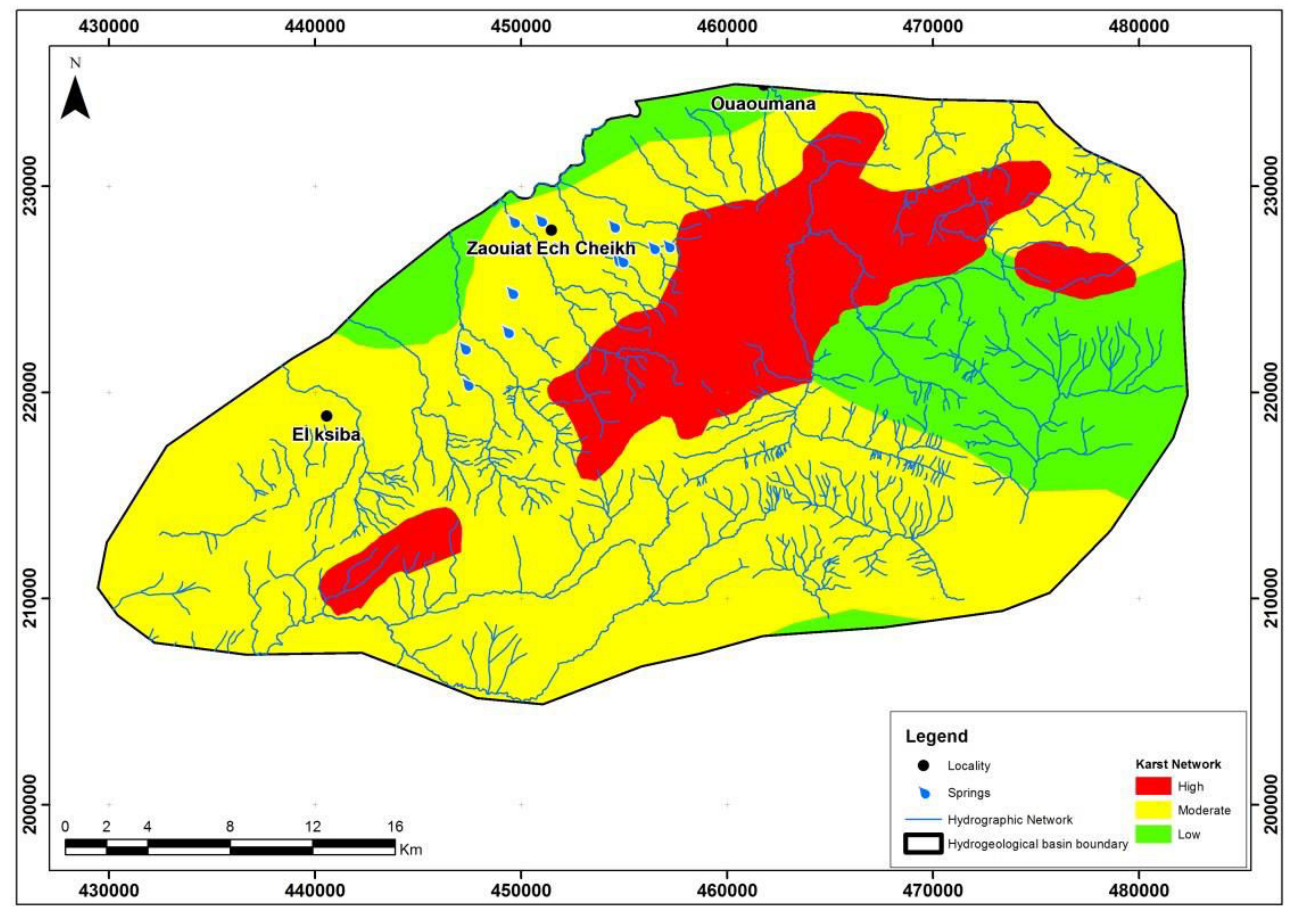

Fig. 8. Karst network development map

\subsection{Protection Factor}

The vulnerability map in Figure 4 shows that the protection factor values vary between 12 and 31. Areas with very high vulnerability, with a protection factor between 12 and 19, correspond to lapiez fields and areas occupied by sinkholes and losses, affecting the relatively bare limestones of the High Atlas as a result of diffuse and concentrated infiltration.

Large high vulnerability ranges (protection factor of 20 to 25) correspond to the zones of passage between the High Atlas and the quaternary formations of Dir where the karstification is less developed with less infiltration with respect to the slope. The best protected areas are those of the plain, characterized by clay and marly formations. The protection factor associated with these zones is 25 to 31 . 


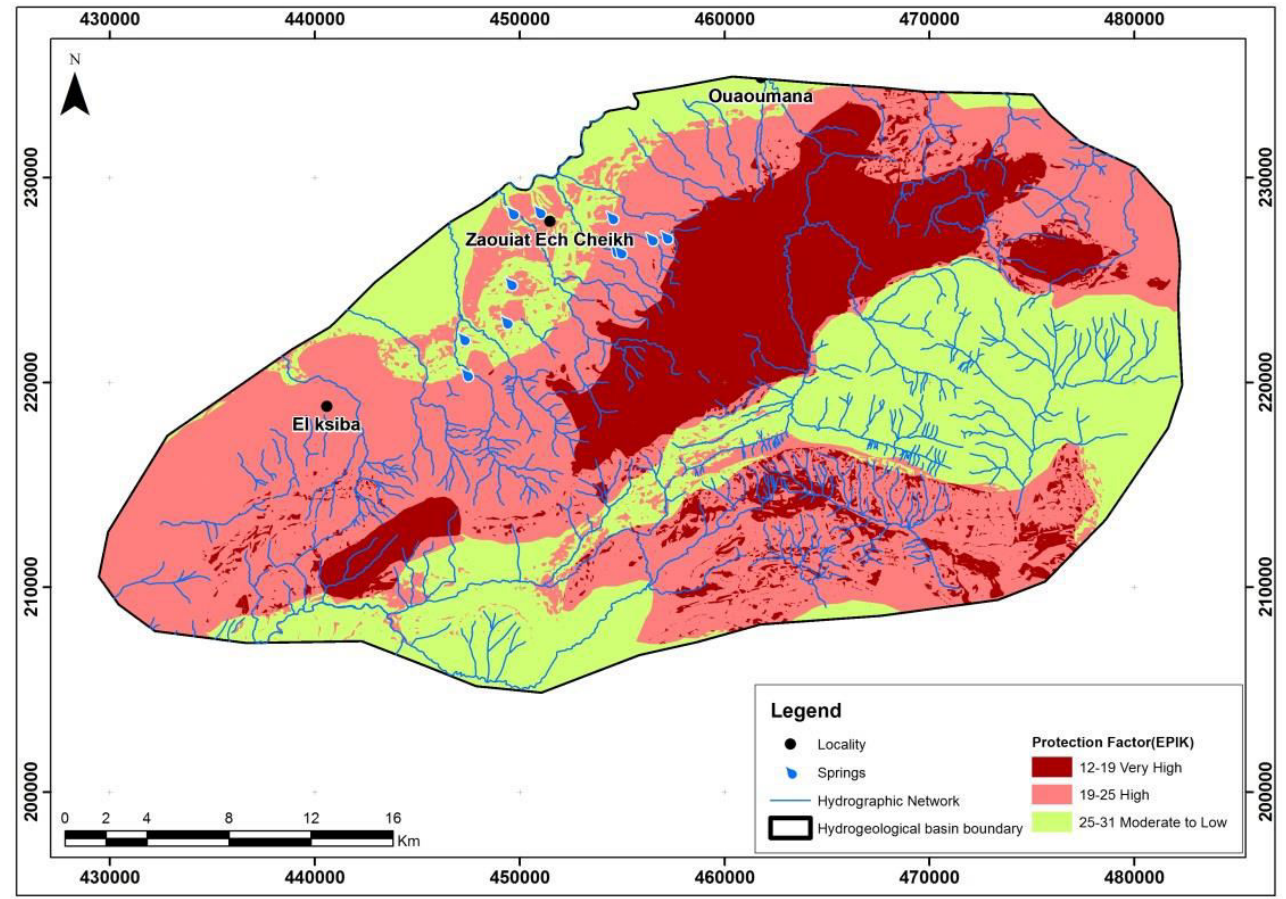

Fig. 9. Spatial distribution of the protection factor (EPIK method)

\section{Conclusion}

The application of the EPIK method has made it possible to map the vulnerability to pollution of sources located between El Ksiba and Ouaoumana. Three classes of vulnerability emerge from the analysis of this map, namely very high, high and moderate to low. The high class is the most dominant in the source watershed.

Vulnerability mapping is a methodology that has become indispensable for the protection of groundwater resources.

\section{Acknowledgements}

We would like to thank all the persons who contributed to the improvement of this work.

\section{References}

1. L. BOUCHAOU, P. CHAUVE, J. MUDRY, J. MANIA et Y. HSISSOU. Structure et fonctionnement d'un hydrosystème karstique de montagne sous climat semi-aride: cas de l'Atlas de Beni-Mellal (Maroc). Article, Journal of African Earth Sciences, Vol. 26, No. 2, pp. 225-236, (1997).

2. ONEP. Etude d'assainissement de la ville d'El Ksiba. Etude d'assainissement. Mission I, volet d'Etude d'impact sur l'environnement, 158 p, (2003).

3. K. EL KHAMMARI, A. NAJINE, M. JAFFAL, T. AÏFA, M. HIMI, D. VASQUEZ, A. CASAS et P. ANDRIEUX. Imagerie combinée géoélectrique-radar géologique des cavités 
souterraines de la ville de Zaouit Ech Cheikh (Maroc). Comptes Rendus Géoscience, Vol. 339, pp. 460-467, (2007).

4. N. DOERFLIGER et F. ZWAHLEN. Cartographie de la vulnérabilité en régions karstiques (EPIK). Guide pratique. L'environnement pratique. Office fédéral de l'environnement, des forêts et du paysage, Berne, 56 p, (1998).

5. N. Doerfliger, P.-Y. Jeannin, F. Zwahlen. Water vulnerability assessment in karst environments: a new method of defining protection areas using a multi-attribute approach and GIS tools (EPIK method).Article, Environmental Geology 39(2):165-176 (1999).

6. LorienneTHÜLER. Estimation et cartographie de la vulnérabilité des aquifères en milieu forestier. Thèse, Faculté des Sciences de l'Université de Neuchâtel, 183 p, (2014).

7. R. EL bardai, K. Targuisti, A. Maaté, M. Maâtouk et J. Stitou. Evaluation de la vulnérabilité à la contamination des nappes karstiques des environs de Chaouen (Rif septentrional, Maroc) : méthode EPIK. Publications del Instituto Geológico y Minero de España. Hidrogeologia y Aguas Subterraneas N 18.239-247. Madrid, (2006).

8. L. BOUCHAOU, P. CHAUVE, J. MANIA, J. MUDRY, J.L. MICHELOT. Apports des traçages artificiel et naturel à la connaissance des circulations et des zones de recharge en région semi-aride cas de l'Atlas de Beni Mellal(Maroc).Article, Revue des Sciences de l'eau 8(1995) 43-55 pp. 